\title{
Case Study of Teacher Leadership Style in Improving Student Discipline
}

\author{
Rahmania Sri Untari \\ Fakultas Keguruan dan Ilmu Pendidikan \\ Universitas Muhammadiyah Sidoarjo \\ Sidoarjo, Indonesia \\ rahmania.sriuntari@umsida.ac.id
}

\author{
Fitria Nur Hasanah \\ Fakultas Keguruan dan Ilmu Pendidikan \\ Universitas Muhammadiyah Sidoarjo \\ Sidoarjo, Indonesia \\ fitrianh@umsida.ac.id
}

\begin{abstract}
Learning activities is a form of a series of behavior between teachers and students in the classroom in achieving learning objectives. Among the forms of student management in the classroom is by disciplining students. Behavior affects teachers to students is a form of teacher leadership to students. Based on the result of research, it is known that: (1) the teacher of TKJ Study Program at SMKN 6 Malang using situational leadership style, and (2) the formulation of teacher leadership effort in improving student discipline that is, (a) intention to change the student's undisciplined attitude, (b) disciple the student with a non violent heart, (d) the undisciplined student is punished in a gentle and educational manner, (e) caring for the student according to the attitude and behavior of each student, (f) Students are accustomed smile to greet the teacher when entering the class, $(\mathrm{g})$ when students are late students are not allowed to enter the classroom but still punished in an educational way, and (h) students who are late to class and do less work every day.
\end{abstract}

\section{Keywords--leadership; style; student discipline}

\section{INTRODUCTION}

Learning activity is a form af a series of behavior between teachers and students in the classrrom in achieving learning objectives. In doing their profession, teachers are demanded to acquire good teaching techniques so they can have great teaching and learning activities. Besides that, tachers must have ability to manage the class. Among the ways of student management in the classroom is by diciplining the students [1]. Student discpline is a state where students are well-organized without violencing any rules that disadvantaging the school directly and indirectly. Student discpline does influemce the teachers to get the objective of the lesson. Dicipliine plays significant role to create a wellorganized class that has effective learning activities without any ,hurdles and it's a requirement for every student. Without discpline, learning activities won't be effective and won't go as it was planned.

Teachers behavior toward students are form of leadership, and because of this teachers can be called as students leader [1]. " teachers are leaders in learning activities and they are called director of learning. Teachers guide and direct students to be educators. They must have energy to influence their students. Their influence comes from teacher leadership ability that they have." As the director of learning, teachers' way to influence the students could determine the success of the objectives to be achieved. Moreover, to discpline the students, teachers neeed to show their influence by using the right leadership. Misehaved teachers will bring disadvantages to them and to the students.

In fact, teachers face different social, economy, culture, and environment background. And this could show the difference of student's emotion, motivation, and behavior [2]. The difference between one another could bring dynamic in the class and teachers are required to do right action iin order to discpline the class. Therefore, teacher action and leadership in diciplining the student can be adapted with situational leadership. This kind of leadership is a form of leaders' behavior in influencing their follower by adapting their readiness that is shown by situation faced by the leaders. In situationalapproach, leadership style must be suitable with the situation faced by the leaders [3].

Teacher leadership and discpline in class, especially in vocational schools is need to br concerned. Vocationl schools must pay close attention to to any activities that focusing on student's abilities, craftmanship, and knowledgein order to prepare them in the job market. As the frontrunners, teachers are related to their students' progress and are responsible for it [1]. Through learning process, teacher leadership becomes one of bridges that can bring students to reach the objective of the lesson. Students' background in SMKN 6 MALANG is middle low class. Therefore, school needs to provide special treatment to improve the discpline of the students.

Based on the interview result conducted on April 19th 2017, with one of computer engineering (TKJ) teacher, Mr. Novia, he described that that vocational schools aim is to create graduates who are ready to work. Besides that, vocational schools need to pay more attention to their students' behavior in order to succeed, and one of the ways to achieve it is by applying class discpline. Class discpline in vocational schools need to be implemented, or it may need to be set as a good culture that can be maintained and improved. 
So, it's clear that students need to have high level of discpline to help them getting skills and knowledge iin their field.

According to Mr. Novia, class discpline becomes one of many responsibilities teachers have in class. Techers were hoped to follow vocational school's vision and mission, especially in directing their students getting things they want to achieve. Due to such condition, Mr.Novia always applying situational leadership to increase the discpline in SMKN 6 MALANG.

Students' problem with discpline in SMKN 6 MALANG isn't only caused by their social background, but also because of their teachers leadership that aren't suitable with theit problemthey face. Right leadership from teachers could bring good discpline from students. Because of that, to examine the suitability of teachers' response towards student discpline, school needs to assess its teachers leadership skills and their ability to discpline the students.

\section{A. Research Focus}

Based on that background, research is focused on teacher leadership style to increase student discpline. The formulation are:

1. What styles used by teacher to improve student discpline in SMKN 6 MALANG?

2. What is the formulation of teacher leadership efforts in improving student discpline?

\section{LITERATURE REVIEW}

\section{A. Teacher leadership in class}

Leadership is a complex process when someone onfluences others to achieve a mission, task, or a goal, and direct organization with some methods to make it more cohesive and logical [4]. Someone who undergo this processuse leadership attributes (belief, values, ethics, knowledge and skills). Leader enable people to have will to achieve their high purpose and goal, where a boss asks his or her people only to achieve a task or a goal [5].

Behavioral leadership shows influenciing or moving people to reach a purpose. Basically, teachers are leaders to their students. And as a leader, teacher has responsibility in developing his or her student's personality, knowledge, and skills for their future. Teacher's behavior as a leader was described by Ki hajar Dewantara[6]. Teacher as a figure Ing Ngarsa Sing Tuladha, Sing Madya Mangun Karsa, Tut Wuri Handayani (the leaders give examples, the middle give will, the back give power), that means teacher leadership must be able to watch their students from behind while giving examples and power to make sure that they are in the correct track.

Leadership behavior is a behavior pattern that is shown by teachers to influence their students through sets of main task in the learning process [7]. Teacher leadership behavior is student's achievment oriented. It's including personality, knowledge, and skills that must be acquired by students through learning activities. Teachers decide and direct students to develop their talents and teach them social and life values, etc.

\section{B. Situational Leadership}

Previous reserah in Ohio and Michigan University have answere the needs to understand leadership that is related to certain situation. There are two things that are done by leaders to their followers in this situational leadership. They are directive behavior and supportive behavior [8].

How far a leader gets inivolved in one way communication, such as defining role, informingthe followers about what is to be done, and monitoring the followers strictly. While supportive behavior is defined as how far a leader involved himself into two ways communication. Such as giving support, facilitating interaction, and involving the followers in making decision [9].

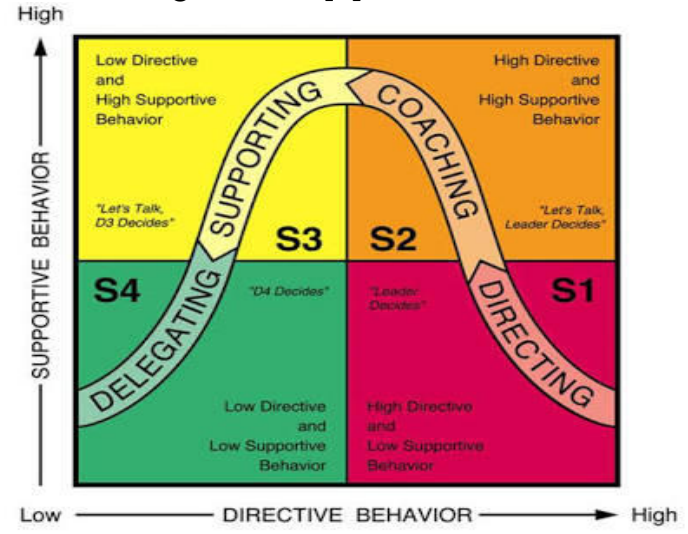

Fig. 1. Four basic leadership styles

Both behavior are put in two different and separate axis. Therefore, readers can understand four basic leaderhip styles.

\section{Student Discpline}

Student discpline is needed to create a good school. Without discpline, school will face probems related to indiciplinary. Discpline that will be examined here is student discpline during learning activities at hous and at school [7].

As a class manager, teachers are requiers to discpline their students. Diciplining the students is teacher's responsibility in conrolling the class in order to get a condusive learning process in class [7]. Class discpline is each student's responsbility. Discpline is adapted with class rules iin order to create a class harmony. Discpline itself has various advantages, such as directing students to have good discpline, being able to recognize good and bad behavior and supporting the continuity of learning process at school. Due to some reasons above, teachers need to apply discpline in class.

\section{METHOD}

This research used qualtative method. Therefore, this research is prioritized to gain understnading rather than statistic. [10] defined qualitative research methodology refers in the broadest sense to reserach that producesdescriptive 
data-people's own written or spoken words and observable behavior.

This research used case study. Case study ia a research method involving a detail examination of a setting, or a subject, document storage, or an event [10]. The subject of this research is determined with purposive sampling. It is a non probability sample that isn't selected by strata, or area but it is based on certain goal that is related to research's aim.

In this case researcher used an informant, that is one key informant, a computer engineering teacher from SMKN 6 MALANG.

To collect the data needed in this research, researcher used three methods, they are:

1. Observation

Observation is one of imiportant tool for data colleting in qualitative method. Observing means paying attention to phenomenon in the field through 5 senses, or even with instruments to record the data fo scinetific purpose [11]. Observation is based on research aim and research question.

\section{Interview}

Interview is divided by 2, structured and unstructured interview [12]. Unstru ctured interview is also called In depth interiew, while structured interview is also known as standardized interview where all interview questions are prepared in advance. Complementary data is collected through interview with a teacher, and researcher used structured interview. This data is used to analyze students' abilities and larning process situation. Data analysis technique involves data reduction (summary), choosing primary things, and looking for pattern from the collected data.

\section{Documentation}

Documentation is notes from previous events according to [13], document can be in written form, pictures, or monumental works of someone. Documentation is done by writing some rules tht are important for research.

\section{RESULT}

Based on research finding, leadership style that was applied by Mr.Novia is situational leadership. The style he used was shown from his answer on interview. That was student learning which was adapted with students abilities. He realized that each student had different skills and readiness. People with low task readiness have low abilities and they feel uncomfortable. People like that need different leadership from people with high task readiness, high iniciative, skillful and confident [14].

When resercher was doing her research in Mr. Novia's class. She saw every student kissed his hands. This action was tajen as on of his ways to increase student discpline, especially values and politeness. When students were ready to start student learning, Mr. Novia always approached students with low abilitis. For skillful students, he only saw them in distance, except when they called him for a help. This condition showed Mr.Novia applied leadership style that was adapted ffrom situation he faced because he lways paid attention to his students' abilities and readiness.

When it is related to situation theory from Hersey and Blanchard, this theory is focus on followers readiness as the key of situation that determine behavioral effectiveness of a leader is a teacher. This situation finally force teacher to ask their student to participate actively and give them motivation to grow optimally.by participating, student will be more confident in doing tasks given to them [15]. This shows that right leadership style shown that leadership style was hoped to be adapted with students' abilities and give good motivation so their discpline will increase. The link between situational leadership and followers readiness can be seen in figure 2 .

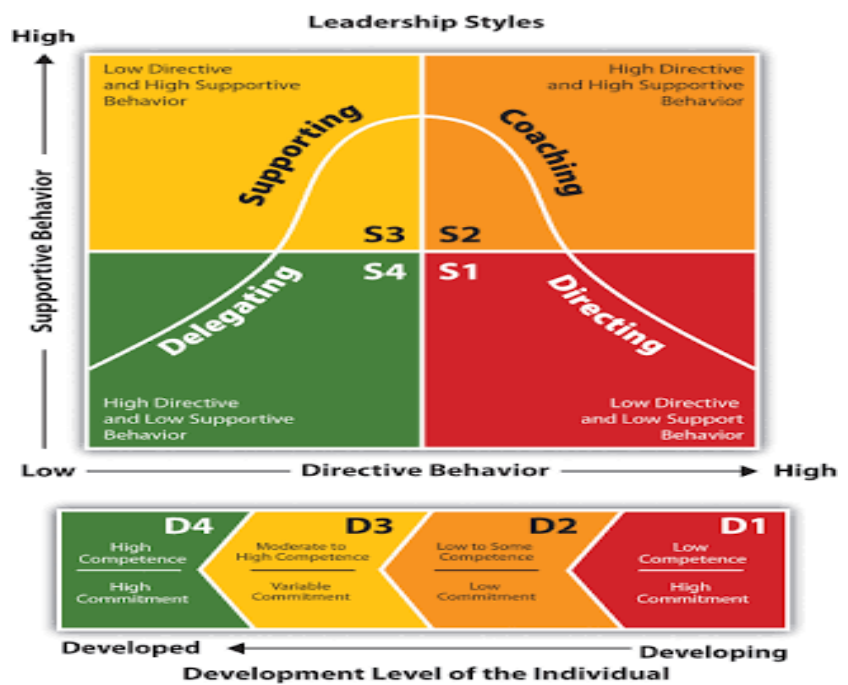

Fig. 2. The link between situational leadership and followers readiness

\section{A. The relationship between situtional leadership and follower readiness}

This theory concludes that leadership role can be adapted with situation and condition in the organization. This theory also different from the previous leadership theories. The previous ones viewed same leadership style can be used in every situation and condition in an organization. In contrast, each oragnization its characteristic that differ from one another. Even same organiation will have different problem.

\section{B. Formulation of Teacher Leadership Effort To Increase Student Discpline}

While the resercher was doing her observation in Mr. Novia's class, he gave punishment to late students or students who didn't do their task. One of the punishment was reciting short sura' in front of the class. Yet some of the students 
weren't allowed to follow lesson in the classroom since they have made chaos inside the class. These efforts were made to make students to be discplined. Efforts that he did were sucessfully made students felt detterent and wouldn't repeat the same mistakes anymore.

Besides that, researcher found Mr.Novia's hard work wasn't done inside the class only, but also outside the class. Even students who he wasn't taught. For example, when students didn't wear uniform neatly or forgot to wear their ties would try to run to avoid him. Surely this showed that Mr. Novia is a well respected teacher who has high discpline.

Teachers are class manager who are responsible in diciplining their class. Diciplining students is teachers responsibility in controlling students in order to support condusive learning processand direct them to the objective of the lesson [1].

Class discpline is each student's responsibility. Discpline is adapted from class rules. And those rules were made to avoid deviant behavior in class.student discpline has many advantages, such as directing students to be discplined, recognizing good and bad behavior for students att school and teach students about their rights and responsibilitie in class. That's why teachers need to mainatain discpline well.

In maintaining discpline, teachers face various students beahvior with diffferent character and teachers need to direct them to get the same goal, that is student discpline. Of course, when facing differences, teachers needs to use different approach that is suitable to infuence student so they will perform good discpline.

\section{CONCLUSION}

Leadership action from a teacher is diciplining his or her teacher can be seen and adapted with situational leadership. From this type of leadership teachers can see and adjust their actions when facing various situation that os liinked with student's readinessin doing discpline which can be shown in certain situation. That is in the implmentation of a task, function, and goal that are related to learning process. From that teacher's action it be seen the effectiveness level of students readiness in applying discpline in certin situation.

\section{ACKNOWLEDGMENT}

This research successfully implemented one of them is because SMKN 6 Malang very support especially teacher of TKJ, that is Mr. Novia. in addition to the great thanks to Mr. Syamsul Hadi as a lecturer of Malang State University who has helped guide in completing this research.

\section{REFERENCES}

[1] Darwin, Sudirman. 2010. Educational Leadership. Bandung: Alfabeta.

[2] Novan, Ardi Wiyani. 2013. Classroom Management. Jogjakarta: AR-RUZZ MEDIA. Education. Jakarta: Gaung Persada Press.
[3] Yulk, Gery. 2002. Leadership in Organization, Publisher Prenhallindo, Jakarta.

[4] Bernardine and Susilo Supardo. 2005. Leadership Basics and Developmentnya.Yogyakarta: CV. Andi keep up.

[5] Hersey, P and Blanchard, KH. 2002. Organizational Behavior Management, Erlangga Publishers, Jakarta.

[6] Martinis, Yamin. 2007. Unit-Based Learning Design.

[7] Nizar, Imam Ahmad Ibnu. 2009. Shaping And Improving Discipline Since Development. Yogyakarta: Andi Offset.

[8] Samson, I. 2007. Effect of Situational Leadership Style on Employee Performance at Ambon City Revenue Service, Arthavidya Journal, Vol. 8, No.1, Journal of Management and Business.

[9] Thoha, Miftah. 2003. Leadership In Management, RajaGrafindo Persada, Jakarta.

[10] Bogdan, R.C. dan S.K.Biklen. 2006. Qualitative Research for Education An Introduction to Theory and Methods Fifth Edition. New York: Pearson.

[11] Creswell, J.W. \& Clark, V.L.P. 2015. Qualitative Research \& Research Design. London: LITERATURE STUDENTS.

[12] Moleong, L.J. 2006. Qualitative Research Methodology. Bandung: Teens Rosdakarya.

[13] Sugiyono. 2008. Quantitative Research Methods, Qualitative, and R \& D. Bandung: Alfabeta.

[14] Dubrin Andrew J. 2005. Leadership (Translation), Prenada Media, Jakarta.

[15] Suyanto. 2009. Knowing Leadership and Management of Nursing at Yogyakarta Hospital, Mitra Cendikia Press. 